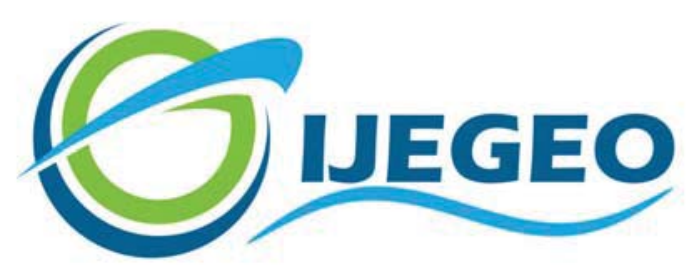

International Journal of Environment and Geoinformatics (IJEGEO) is an international, multidisciplinary, peer reviewed, open access journal.

\title{
Assessment of Vehicular Greenhouse Gas Emissions and Potentials for Reduction in a University Campus: Case Study of Bayero University Kano
}

\section{Richard Balthi MSHELIA, Titus Yusuf JIBATSWEN, Funsho BABARINDE, Rabo YUSUF}

\author{
Chief in Editor \\ Prof. Dr. Cem Gazioğlu \\ Co-Editors \\ Prof. Dr. Dursun Zafer Şeker, Prof. Dr. Şinasi Kaya, \\ Prof. Dr. Ayşegül Tanık and Assist. Prof. Dr. Volkan Demir
}

Editorial Committee (September 2021)

Assoc. Prof. Dr. Abdullah Aksu (TR), Assit. Prof. Dr. Uğur Algancı (TR), Prof. Dr. Bedri Alpar (TR), Assoc. Prof. Dr. Aslı Aslan (US), Prof. Dr. Levent Bat (TR), Prof. Dr. Paul Bates (UK), İrşad Bayırhan (TR), Prof. Dr. Bülent Bayram (TR), Prof. Dr. Luis M. Botana (ES), Prof. Dr. Nuray Çağlar (TR), Prof. Dr. Sukanta Dash (IN), Dr. Soofia T. Elias (UK), Prof. Dr. A. Evren Erginal (TR), Assoc. Prof. Dr. Cüneyt Erenoğlu (TR), Dr. Dieter Fritsch (DE), Prof. Dr. Çiğdem Göksel (TR), Prof.Dr. Lena Halounova (CZ), Prof. Dr. Manik Kalubarme (IN), Dr. Hakan Kaya (TR), Assist. Prof. Dr. Serkan Kükrer (TR), Assoc. Prof. Dr. Maged Marghany (MY), Prof. Dr. Michael Meadows (ZA), Prof. Dr. Nebiye Musaoğlu (TR), Prof. Dr. Masafumi Nakagawa (JP), Prof. Dr. Hasan Özdemir (TR), Prof. Dr. Chryssy Potsiou (GR), Prof. Dr. Erol Sarı (TR), Prof. Dr. Maria Paradiso (IT), Prof. Dr. Petros Patias (GR), Prof. Dr. Elif Sertel (TR), Prof. Dr. Nüket Sivri (TR), Prof. Dr. Füsun Balık Şanlı (TR), Prof. Dr. Uğur Şanlı (TR), Duygu Ülker (TR), Prof. Dr. Seyfettin Taş (TR), Assoc. Prof. Dr. Ömer Suat Taşkın (TR), Assist. Prof. Dr. Tuba Ünsal (TR), Dr. Manousos Valyrakis (UK), Dr. İnese Varna (LV), Dr. Petra Visser (NL), Prof. Dr. Selma Ünlü (TR), Assoc. Prof. Dr. Oral Yağcı (TR), Prof. Dr. Murat Yakar (TR), Assoc. Prof. Dr. İ. Noyan Yılmaz (AU); Assit. Prof. Dr. Sibel Zeki (TR)

Abstracting and Indexing: TR DIZIN, DOAJ, Index Copernicus, OAJ, Scientific Indexing Services, International Scientific Indexing, Journal Factor, Google Scholar, Ulrich's Periodicals Directory, WorldCat, DRJI, ResearchBib, SOBIAD 


\title{
Assessment of Vehicular Greenhouse Gas Emissions and Potentials for Reduction in a University Campus: Case Study of Bayero University Kano
}

\author{
Richard Balthi Mshelia $^{1, *(i)}$, Titus Yusuf Jibatswen ${ }^{2}$ (D) Funsho Babarinde $^{3 \text { (i) }}$, Rabo Yusuf ${ }^{4}$ iD \\ ${ }^{1}$ Department of Mechanical Engineering, Faculty of Engineering, Bayero University, Kano. Kano State, NIGERIA \\ ${ }^{2}$ Department of Mechanical Engineering, College of Engineering, Federal University Agriculture, Makurdi. Benue State, NIGERIA \\ ${ }^{3}$ Department of Mechanical Engineering, Faculty of Engineering, Federal Polytechnic, Ilaro, Ogun State, NIGERIA \\ ${ }^{4}$ Department of Technical Education, Faculty of Technology, Kaduna State College of Education, Gidan Waya, Kaduna State, NIGERIA \\ * Corresponding author: R. B. Mshelia \\ Received: 15 Jan 2020 \\ E-mail: rbmshelia@gmail.com \\ Accepted: 14 Feb 2021 \\ How to cite: Mshelia et al., (2021). Assessment of Vehicular Greenhouse Gas Emissions and Potentials for Reduction in A University Campus: \\ Case Study of Bayero University Kano, International Journal of Environment and Environment and Geoinformatics (IJEGEO), 8(3):301-306. \\ doi. $10.30897 /$ iiegeo. 837262
}

\begin{abstract}
Globally, the transport sector is responsible for the emission of $30 \%$ of all anthropogenic greenhouse gases (GHGs) which are the main reason behind the change in the climate and accelerated warming of the globe. This research estimated the emission of GHGs from vehicles in Bayero University, Kano and also established the pattern of vehicular GHG emissions on the campus taking into consideration the peculiarities of the transport systems on Nigerian university campuses. Data for the study were collected by issuing out questionnaires to residents of the campus and then manually enumerating the number and types of vehicles entering the campus through its main entrance. Using standard guidelines for estimation of emission of GHGs, the campus' vehicular carbon footprint was estimated and its pattern of emission established. It was found that the total annual vehicular GHGs emission for the campus is $2,360.22 \mathrm{tCO}_{2} \mathrm{e}$, with motorcycles, sedans, buses, tricycles and trucks having $21.2 \%, 43.2 \%, 30.5 \%, 2 \%$ and $2.2 \%$ share of the emission respectively. Scenarios for reduction of emission on the campus were simulated, it was found that the use of bicycles in place of motorcycles and compressed natural gas buses in place of the conventional diesel and petrol powered ones have a potential of reducing emissions on the campus by $21 \%$ and $26 \%$ respectively. It was suggested that measures to curtail usage of private cars and motorcycles on the campus be introduced so as to make the transport sector sustainable and set the campus on the path to carbon neutrality.
\end{abstract}

Keywords: Carbon footprint, Emission factor, Emission reduction, Global warming, Greenhouse gases, Transportation.

\section{Introduction}

Anthropogenic emissions of greenhouse gas (GHG) into the atmosphere has been on the rise since the discovery of oil. This increase in the amount of GHGs in the atmosphere has been identified as the major reason for rise in the average global temperature and the accelerated change in the world's climate (Dodman, 2009; Duan, et al., 2006; Hiller, 2011; Weitzman, 2012; Ülker et al., 2018; Mersin et al., 2019, 2020). The peak of this steady increase in global temperatures was reached in the year 2016 which on record is the warmest year ever (Boykoff, et al., 2019). Other changes in the climate being observed in recent times globally include generalised melting of glaciers which leads to rise in sea levels and submerging of coastal towns and islands, multiplicity of heat waves, droughts, cyclones and torrential rains (Roeckner, et al., 2007; Tan et al., 2021).

The rise in the emission of GHGs became more pronounced after World War II when western nations began to rebuild their lives, industrialisation became the order of the day, more young people became employed and had more disposable income ( $\mathrm{Li}$ and Lin, 2015; McConnell et al., 2007; Price, et al., 1998; Xu and Lin, 2015). The increase in disposable income in the hands of the newly employed and cheaper prices of automobiles occasioned by improvement in the vehicle manufacturing process meant an increase in the number of vehicles being manufactured and bought. In the United States alone, the Committee for Economic Development estimated that during the "first full postwar year" there was an increase of $75.8 \%$ in the number of cars produced, this meant in the first full post-war year, 6.8 million units of cars were produced in the country (Huddle, 1945). According to IPCC (2014), vehicles produced an estimated 7 gigatonne of carbon dioxide equivalent $\left(\mathrm{GtCO}_{2} \mathrm{eq}\right)$ of direct $\mathrm{GHG}$ emissions in the year 2010 thus making emissions from vehicles responsible for approximately $23 \%$ of total GHG emissions. In Nigeria, it is estimated that this value is much higher, $35 \%$ of GHGs emission in the country are from vehicles (Index Mundi, 2014). Without aggressive and sustained mitigation policies being implemented, transport emissions could increase at a faster rate than emissions from the other energy end-user sectors and reach around $12 \mathrm{GtCO}_{2} \mathrm{eq} / \mathrm{yr}$ by 2050 (IPCC, 2014; Ülker et al., 2020; Mersin, 2020; Bayırhan et al., 2019; Tokuşlu, 2021).

University Campuses and other institutions of higher learning are usually clusters where high energy 
consumption and emission of GHGs exist. For example, in the United States, college campuses account for approximately $3 \%$ of the country's GHGs emission despite these campuses having less than $1 \%$ of the population in the country (Sinha, Schew, Sawant, Kolwaite, and Sarah, 2012). In other places like Korea, this value is up to $5 \%$ of the Nation's GHGs emission. Higher institutions of learning having higher per capita emission of GHGs means there is need to reduce these emissions, reduction in the emissions first entails understanding the sources and patterns of emissions. In other countries, particularly western nations, the carbon footprints of institutions of higher learning have been assessed and are known. Unfortunately, most Nigerian Universities despite being citadels of learning and an example to the wider society do not have a record of the GHGs emission. For these institutions to lead by example and ensure that the commitment of Nigeria to reduce its current GHG emissions by $50 \%$ by the year 2030 in accordance to the 2015 Paris Climate Agreement becomes a reality, first the pattern of emissions in these campuses need to be understood. Bayero University, Kano (BUK) being a typical example of a university campus in Nigeria is used as a case study to understand the pattern of emission of GHGs from vehicles in University campuses in Nigeria, it is expected that this research will provide stakeholders information that can be used as a guide to making informed choices for implementation and also provide data for further research while also suggesting suitable strategies which can serve as a basis for policy formulation for the reduction of greenhouse gas emissions from vehicles on campuses.

\section{Materials and Methods Data collection}

From observation, it was noted that there are six different categories of vehicles that ply the roads of BUK New campus, these are: sedans; buses; trucks; tricycles and motorcycles. Data collection and subsequent analysis were done based on these categories. However, it was noted that the difference in the emission factor of buses was negligible, therefore they were considered as one entity in this study.

Questionnaires, manual polling of vehicular traffic and sourcing of information from tables and in literature were used to collect the data for this research. For determination of vehicles domiciled on the campus, questionnaires were issued to the residents. While for vehicles daily commuting in and out of the campus, their numbers and categories in which these vehicles fall into were determined by taking record of the numbers of each category of vehicle that enters the campus through its main entrance between 06:00 hours and 23:59 hours for three weekdays and a weekend.

The following assumptions were made:

1. No vehicle resident on the campus is polled as part of the vehicles entering the campus.
2. All vehicles entering the campus use the main entrance.

The average distance covered by each vehicle is 2.4 kilometres: this is the measured to and fro distance between the main gate to the Administrative Block.

\section{Data Analysis}

IPCC (2006) guidelines for assessment of GHG emissions were used to calculate the emissions in each of the categories being studied. The IPCC tier 1 method for estimation of GHG emissions was used, this method involves the use of default emission factors obtained from literature for estimations, it is less detailed than tier 2 and tier 3 methods which make use of more detailed and specific emission factors (IPCC, 2006). Essentially, default emission factors are used together with activities data obtained to determine the total emission from the subject being studied.

For vehicles entering the campus and those resident on the campus, the general formula in equation 1 below was used to determine the emission of each category of vehicle.

$$
A E=N V \times A T D \times E F \times 365
$$

Where

$\mathrm{AE}=$ Annual Emission

$\mathrm{NV}=$ Number of each category of vehicle

ATD $=$ Average Travel Distance

$\mathrm{EF}=$ Emission Factor.

Where the emission factor for each category of vehicle is thus:

Motorcycles $=0.12761 \mathrm{kgCO}_{2} \mathrm{e} / \mathrm{km}(\mathrm{WRI}, 2008)$

Sedans $=0.23398 \mathrm{kgCO}_{2} \mathrm{e} / \mathrm{km} \quad($ IPCC, 2006)

Buses $=0.88634 \mathrm{kgCO}_{2} \mathrm{e} / \mathrm{km} \quad$ (IPCC, 2006)

Tricycles $=0.1860 \mathrm{kgCO}_{2} \mathrm{e} / \mathrm{km} \quad$ (IES, 2004)

Trucks $=0.99976 \mathrm{kgCO}_{2} \mathrm{e} / \mathrm{km} \quad$ (IPCC, 2006)

To test the impact sustainable transportation means will have on the carbon footprint of the campus, four scenarios were tested. Each of the four scenarios have been shown to have an impact on the reduction of carbon emission from the transportation sector (Hao, et al., 2017; Khan, et al., 2015; Maizlish, et al., 2017). The scenarios tested are:

1. Bicycles replace motorcycles.

2. Buses run on compressed natural gas (CNG) instead of petrol or diesel

3. All sedans are electric vehicles (EVs)

4. Combination of all 3 scenarios above.

For the first scenario, all emissions from use of motorcycles were eliminated. This gives a picture of how the campus' transportation carbon footprint will look when all motorcycles are banned and their users encouraged to use bicycles. In the second scenario where buses running on gasoline are altered to run on $\mathrm{CNG}$ or replaced entirely with those that run on $\mathrm{CNG}$, the emission factor for CNG buses was used to estimate the 
emission from all the buses plying the roads on the campus. It was found in literature that the emission factor of $\mathrm{CNG}$ is $0.1276 \mathrm{kgCO}_{2} \mathrm{e} / \mathrm{km}$ (Skrucany, et al., 2017).

For the third scenario where all sedans which traditionally run on petrol and diesel are now EVs, the emission of GHGs from this category of vehicles is eliminated completely since this analysis considers the carbon footprint on a thank-to-wheel basis (direct emission) and not well-to-wheel basis (indirect emission). The fourth scenario examined is a mashup of the first three, this a futuristic scenario where carbon emission from the transport system of the campus is reduced to a bare minimum.

\section{Results \\ Pattern of Emissions on the Campus}

The study found that there are an estimated 289 vehicles resident on the campus, while an average of 4,850 vehicles commutes in and out of the campus through the campus' main gate daily. While on an annual basis, an estimated 3,822,028 pass through the campus' main gate, while the vehicles resident on campus make an estimated 105,485 trips annually. The breakdown for each category of vehicle being analysed that enters the campus through its main entrance is presented in Table 1.

Table 1: Annual traffic volume on the campus

\begin{tabular}{|c|c|c|c|c|}
\hline \multirow[t]{2}{*}{ Vehicle } & \multicolumn{3}{|c|}{ Number } & \multirow[t]{2}{*}{ Total } \\
\hline & $\begin{array}{l}\text { Resident } \\
\text { Campus }\end{array}$ & on & $\begin{array}{l}\text { Daily } \\
\text { Commute }\end{array}$ & \\
\hline $\begin{array}{l}\text { Motorcyc } \\
\text { les }\end{array}$ & 28,470 & & $1,605,012$ & $\begin{array}{l}1,633,4 \\
82\end{array}$ \\
\hline Sedans & 46,720 & & $1,770,414$ & $\begin{array}{l}\mathbf{1 , 8 1 7 , 1} \\
34\end{array}$ \\
\hline Buses & 13,870 & & 324,923 & $\begin{array}{l}338,79 \\
3\end{array}$ \\
\hline Tricycles & 16,425 & & 92,135 & $\begin{array}{l}108,56 \\
0\end{array}$ \\
\hline Trucks & 0 & & 29,544 & 29,544 \\
\hline Total & 105,485 & & $3,822,028$ & $\begin{array}{l}3,927,5 \\
13\end{array}$ \\
\hline
\end{tabular}

As seen in Table 1 one above, there are more motorcycles and sedans plying the roads of BUK new campus, this is commensurate with the assertion that due to lower income levels, motorcycles are the preferred vehicles of use in most developing countries (Akl, Akl, Eriksson, Gifford, and Koustuv, 2018; Nyagwui, Fredinah, Che, and Yulia, 2016; Olubomehin, 2012). The high volume of motorcycles on the University Campus can be said to be unique to Nigerian University campuses as this was not observed in other studies done on other campuses, particularly those done in richer nations where public transportation systems are more effective or students are affluent enough to own cars (Groode and Heywood, 2004; Letete, et al., 2011; Wara and Ologun, 2012). Tricycles are the most widely used means of public transportation in Nigeria (Odeyemi, et al., 2019; Ogunsemoyin, et al., 2019), that however is not reflected on the campus as seen in Table 1 above. Tricycles constitute just about $3 \%$ of the vehicular traffic on this campus; this is because there is a strict regulation on the movement of commercial tricycles on the campus for security purposes.

It was also determined that the estimated total annual vehicular GHG emission in BUK new campus is $2360.22 \mathrm{tCO}_{2} \mathrm{e}$. The distribution of this total annual emission on the campus according to the categories being studied is presented in Table 2 .

Table 2: GHGs Emission by category of vehicle

\begin{tabular}{|c|c|c|}
\hline Vehicle & $\begin{array}{c}\text { Emission } \\
\left(\mathrm{tCO}_{2} \mathrm{e}\right)\end{array}$ & $\begin{array}{c}\text { Total } \\
(\%)\end{array}$ \\
\hline Motorcycles & 500.28 & 21.2 \\
\hline Sedans & 1020.42 & 43.2 \\
\hline Buses & 720.69 & 30.5 \\
\hline Tricycles & 56.97 & 2.0 \\
\hline Trucks & 61.86 & 2.2 \\
\hline Total & 2360.22 & 100 \\
\hline
\end{tabular}

As seen in Table 2 above, close to half of all the campus' vehicular GHG emissions are from sedans, making emissions from sedans the highest of all the categories of vehicles being studied. Forty-one percent $(41 \%)$ of the number of vehicles plying the roads of the campus are motorcycles, this however is not reflected in the emission from this category of vehicles as only $21 \%$ of the emissions of the campus are from motorcycles. Trucks and tricycles are the least emitters on the campus, they are responsible for just about $4.2 \%$ of the total emissions of GHGs on the campus, and this is not surprising because they are responsible for only $0.8 \%$ and $2.8 \%$ of the volume of traffic on the campus.

Curiously, buses, even though they constitute just about $8.36 \%$ of the vehicular traffic on the campus, they are however responsible for $30.5 \%$ of the campuses emission. Superficially, it can be judged that buses are the highest emitters of GHGs. But when considered thoroughly and juxtaposed with motorcycles, perhaps it can be said that the emission is somewhat acceptable. This is so because buses typically carry more people than motorcycles which at most carries just two people. So, on a per passenger basis, both categories of vehicles have somewhat equal carbon footprint.

Figures 1 and 2 graphically present a comparison between the percentages of volume of traffic and emission for each of the categories of vehicles being considered and then the graphical view of the summary of the pattern of vehicular greenhouse gases emission on the new campus of BUK respectively.

\section{Scenarios}

For the first scenario where the emission from motorcycles are eliminated when a policy banning the use of motorcycles is enacted on the campus and students are encouraged to use bicycles, it was found that the campus' transportation footprint reduces by $21.2 \%$ $\left(500.28 \mathrm{tCO}_{2} \mathrm{e}\right)$. This is far higher than the potential $5 \%$ 
reduction found in New Zealand (Neves and Brand, 2019) and 7\% found in Chile (Vásquez, et al., 2015). In a relatable term, the emission reduction that can be achieved by switching from motorcycles to bicycles on the campus in a year is equivalent to the amount of $\mathrm{CO}_{2}$ that will be removed from the atmosphere by 12,827 trees in a year.

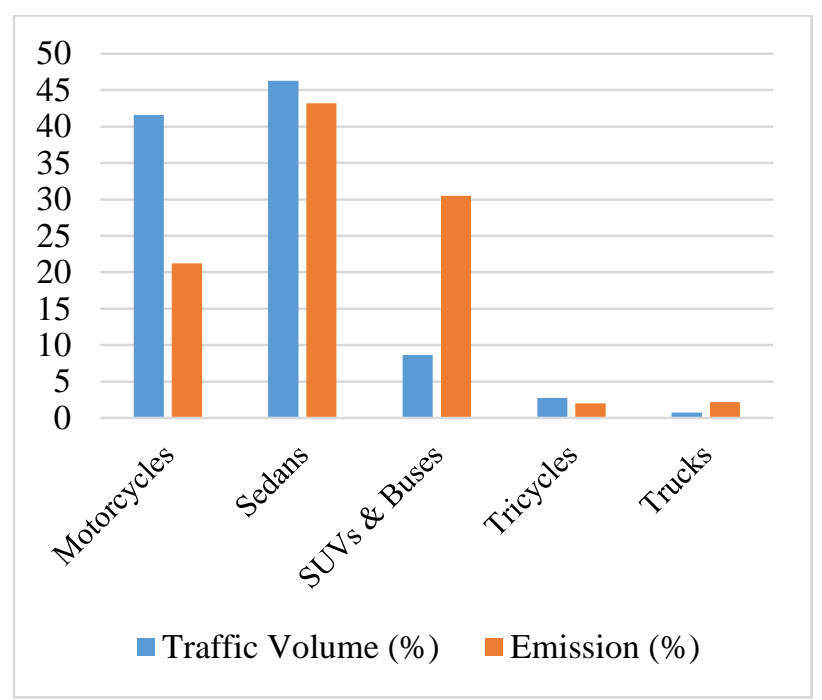

Figure 1: Traffic Volume and Corresponding GHG Emissions

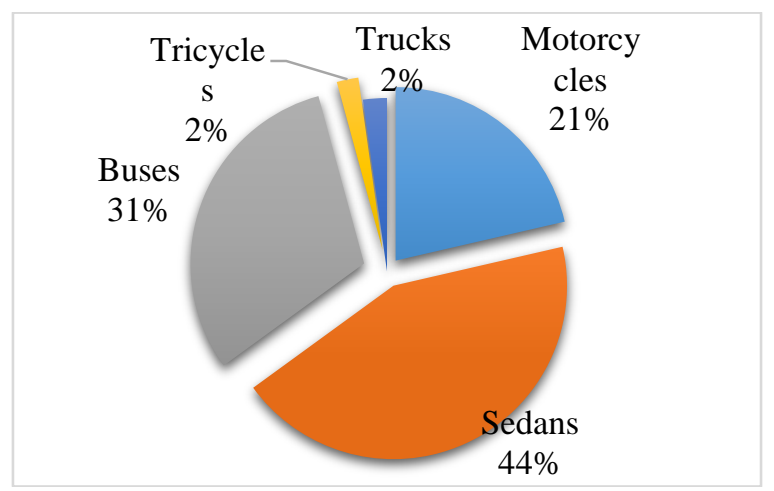

Figure 2: Summary of Vehicular GHGs Emission Pattern

The second scenario envisages a situation where the buses on the campus are upgraded to run on $\mathrm{CNG}$ instead of petrol or diesel. If a policy supporting such is implemented on the campus, it was found that the emission from buses will reduce from $720.69 \mathrm{tCO}_{2} \mathrm{e} / \mathrm{yr}$ to $103.75 \mathrm{tCO} 2 \mathrm{e} / \mathrm{yr}$. This represents an $85 \%$ reduction in the emission of GHGs from buses and a $26 \%$ reduction in the total transportation carbon footprint of the campus. The potential success to be recorded by the use of this sustainable transportation scheme as examined in this scenario is slightly higher than those found in similar studies, in Ireland it was found that the usage of CNG buses will reduce emissions by $63 \%$ (Ryan and Caulfield, 2010).

For the $3^{\text {rd }}$ scenario where all sedans are assumed to be EVs, it means the whole emission from all 1,817,134 trips made by sedans on the campus is eliminated. This brings about the reduction of the campus' transportation carbon footprint from 2,360.22tCOe/yr to $1,339.80 \mathrm{tCOe} / \mathrm{yr}$. The $43.2 \%$ reduction in the GHGs emission of the campus by this singular action is enormous and on course to making the campus green. That notwithstanding, it is pertinent to note that in all the literature consulted in the course of this research, there is no record of any campus where such drastic measure has been taken as such this scenario may be well ahead of its time thus not likely to be taken in the nearest future especially considering the unstable nature of electricity in Nigeria and the low penetration of EVs into the larger scheme of transportation in the country.

The $4^{\text {th }}$ scenario where bicycles replace all motorcycles, buses are converted to run on CNG and all sedans are EVs is a drastic and futuristic one. However, for academic and planning purposes, it is being projected and studied. Estimations made showed that in the instance when the scenario envisaged happens, the campus' transportation carbon footprint will reduce by $90 \%$. By all standards, this is a huge achievement. A $90 \%$ reduction in the emission of GHGs from the transportation sector sets the campus on a firm path to being sustainable and achieving carbon neutrality.

These scenarios show that when measures are taken to reduce the carbon footprint of the campus, significant achievements will be made. Table 3 shows the four different scenarios and their potential impact on the campus' transportation carbon footprint. It can be seen that the highest potential reduction GHGs emission comes from scenario that is quite obvious since it is a combination of the measures taken in the first three scenarios. Sedans were found to be the highest polluters on the campus, it is not surprising that replacing the conventional petrol and diesel powered sedans with electric ones brings about a $43 \%$ reduction in the campus' carbon footprint thus making scenario 3 the second best option. Even though scenarios 1 and 2 as seen in the table pose a reduction of $21 \%$ and $26 \%$ respectively, these are the most likely implementable actions in the nearest future since they are less expensive and more realistic than asking all petrol and diesel sedans owners to switch to EVs especially in a country like Nigeria where the purchasing power is low and electricity unstable.

Table 3: Potential Emission Reduction for all Scenarios

\begin{tabular}{lcc} 
Scenario & $\begin{array}{c}\text { Total Reduction } \\
\left(\mathbf{t C O} \mathbf{O}_{\mathbf{2}} \mathbf{e}\right)\end{array}$ & $\begin{array}{c}\text { Total Reduction } \\
(\mathbf{\%})\end{array}$ \\
\hline Scenario 1 & 500.28 & 21 \\
Scenario 2 & 616.94 & 26 \\
Scenario 3 & $1,020.42$ & 43 \\
Scenario 4 & $1,624.45$ & 90 \\
\hline
\end{tabular}

\section{Conclusion}

After conducting an assessment of the vehicular GHG emissions pattern of a typical Nigerian University, using the new campus of Bayero University Kano as a case study, it was found that the campus emits an estimated 2360.22 $\mathrm{tCO}_{2} \mathrm{e}$ annually from the commuting of staff and 
students. It was also found that there are more sedans plying the routes on campus than any other category of vehicles. This research was able to determine that there is high usage of motorcycles on the campus, and it was noted to be unique to BUK as this was not observed in studies done elsewhere. It therefore can be deduced that this is probably a general trend for campuses in low income countries where the public transport system is not effective and the students are not affluent enough to own cars but are able to own motorcycles. This assertion however needs to be verified by conducting a study on another university campus that has similar socioeconomic demography as BUK.

To test the potential for reduction of GHG emissions on the campus, scenarios were developed and simulated. It was found that making the buses on the campus to run on CNG and enacting a policy that restricts usage of motorcycles and encourages the use of bicycles among students and staff are the most likely implementable of the four scenarios simulated and have the potential of reducing the campus' transportation emissions by $47 \%$. Having a functional mass transit system on the campus equally has the potential of reducing the emissions on the campus, this has been tested and proven to be effective in other institutions (Cheng, et al., 2016; Cheng, et al., 2018; Song et al., 2018; Yan and Crookes, 2009). In the immediate, students and staff should be made aware of their carbon footprint and the need to reduce it so as to have a sustainable campus and play their role in reducing global warming. Since sedans were found to be the highest polluters on campus, a toll can be introduced for private car owners so as to encourage them to switch to a more environmentally friendly means of transportation.

\section{Acknowledgements}

The authors wish to thank the management and staff of Bayero University, Kano for granting permission to carry out the study on their campus and providing them with the necessary support.

\section{References}

Akl, Z., Akl, M., Eriksson, C., Gifford, M., and Koustuv, D. (2018). Evaluating Helmet Use Among Motorcycle Drivers in Lebanon. The Open Public Health Journal, 11(1).

Bayırhan, İ., Mersin, K., Tokuşlu, A., Gazioğlu, C. (2019). Modelling of Ship Originated Exhaust Gas Emissions in the Strait of Istanbul (Bosphorus), International Journal of Environment and Geoinformatics, 6(3), 238-243, doi. 10.30897 /ijegeo.641397

Boykoff, M., Katzung, J., and Nacu-Schmidt, A. (2019). Media and Climate Change Observatory Monthly Summary: The Earth is facing a climate change deadline-Issue 26, February 2019.

Cheng, H., Madanat, S., and Horvath, A. (2016). Planning hierarchical urban transit systems for reductions in greenhouse gas emissions. Transportation Research Part D: Transport and
Environment, 49, 44-58.

Cheng, H., Mao, C., Madanat, S., and Horvath, A. (2018). Minimizing the total costs of urban transit systems can reduce greenhouse gas emissions: The case of San Francisco. Transport Policy, 66, 40 48.

Dodman, D. (2009). Blaming cities for climate change? An analysis of urban greenhouse gas emissions inventories. Environment and Urbanization, 21(1), 185-201.

Duan, A., Wu, G., Zhang, Q., and Liu, Y. (2006). New proofs of the recent climate warming over the Tibetan Plateau as a result of the increasing greenhouse gases emissions. Chinese Science Bulletin, 51(11), 1396-1400.

Groode, T. A., and Heywood, J. B. (2004). A Methodology for Assessing MIT 's Energy Use and Greenhouse Gas Emissions. Cambridge.

Hao, H., Cheng, X., Liu, Z., and Zhao, F. (2017). Electric vehicles for greenhouse gas reduction in China: A cost-effectiveness analysis. Transportation Research Part D: Transport and Environment, 56, 68-84.

Hiller, A. (2011). Climate change and individual responsibility. The Monist, 94(3), 349-368.

Huddle, F. P. (1945). Automobiles in the Postwar Economy.

IES. (2004). Integrated Environmental StrategiesPhilippines Project Report/Metropolitan Manila: A Focus on the Transport Sector. Manila: Citeseer.

Index Mundi. (2014). Nigeria - CO2 emissions from transport.

IPCC. (2006). IPCC Guidelines for National Greenhouse Gas Inventories. New York: Cambridge University Press.

IPCC. (2014). Climate Change 2014 Mitigation of Climate Change Working Group III Contribution to the Fifth Assessment Report of the Intergovernmental Panel on Climate Change.

Khan, M. I., Yasmin, T., and Shakoor, A. (2015). Technical overview of compressed natural gas (CNG) as a transportation fuel. Renewable and Sustainable Energy Reviews, 51, 785-797.

Letete, T. C. M., Mungwe, N. W., Guma, M., and Marquard, A. (2011). 2011 - Carbon footprint of the University of Cape Town. Journal of Energy in Southern Africa, 22(2), 2-12.

Li, K., and Lin, B. (2015). Impacts of urbanization and industrialization on energy consumption/CO2 emissions: does the level of development matter? Renewable and Sustainable Energy Reviews, 52, 1107-1122.

Maizlish, N., Linesch, N. J., and Woodcock, J. (2017). Health and greenhouse gas mitigation benefits of ambitious expansion of cycling, walking, and transit in California. Journal of Transport and Health, 6, 490-500, doi.org/10.1016/ j.jth.2017.04.011

Mersin, K. (2020). Review of total emission of transit Shipsin the Dardanelle which including possible CO2 emission of 1915 Canakkale Bridge, Thermal Science 24 (Suppl. 1), 391-398

McConnell, J. R., Edwards, R., Kok, G. L., Flanner, M. 
G., Zender, C. S., Saltzman, E. S., Kahl, J. D. W. (2007). 20th-century industrial black carbon emissions altered arctic climate forcing. Science, 317(5843), 1381-1384.

Mersin, K., Bayırhan, İ., Gazioğlu, C. (2020). Analysis of the Effects of $\mathrm{CO} 2$ Emissions Sourced by Commercial Marine Fleet by using Energy Efficiency Design Index, Thermal Science, 24(1).187-197.

Mersin, K., Bayırhan, İ., Gazioğlu, C. (2019). Review of C02 Emission and Reducing Methods in Maritime Transportation, Thermal Science, 23(6).73-79. doi.org/10.2298/TSCI190722372M.

Neves, A., and Brand, C. (2019). Assessing the potential for carbon emissions savings from replacing short car trips with walking and cycling using a mixed GPS-travel diary approach. Transportation Research Part A: Policy and Practice, 123, 130146, doi.org/10.1016/j.tra.2018.08.022

Nyagwui, A. E., Fredinah, N., Che, L. B., and Yulia, B. (2016). Motorcycle injury among secondary school students in the Tiko municipality, Cameroon. Pan African Medical Journal, 24(1).

Odeyemi, T. I., Basirka, I. A., and Dickson, O. F. (2019). "Two Versus Four - Wheeler?": Confusing Traffic Regulations and Tricycle Riders in Kano Metropolis (50).

Ogunsemoyin, O., Kabir, H., and Isyaku, M. (2019). Debunking Popular Adaidaita-Sahu Riders: The Kano Experience (No. 52).

Olubomehin, O. O. (2012). The development and impact of motorcycles as means of commercial transportation in Nigeria. Research on Humanities and Social Sciences, 2(6).

Price, L., Michaelis, L., Worrell, E., and Khrushch, M. (1998). Sectoral trends and driving forces of global energy use and greenhouse gas emissions. Mitigation and Adaptation Strategies for Global Change, 3(2-4), 263-319.

Roeckner, K. G., Hansen, J., Schnitzler, K. G., Strassmann, K., and Doney, S. (2007). Climate Change and Trace Gases. Phil Trans and Roy Publishers.

Ryan, F., and Caulfield, B. (2010). Examining the benefits of using bio-CNG in urban bus operations. Transportation Research Part D: Transport and Environment, 15(6), 362-365.

Sinha, P., Schew, W. A., Sawant, A., Kolwaite, K. J., and Sarah, A. (2012). Greenhouse Gas Emissions from U.S. Institutions of Higher Education. Journal of the Air and Waste Management Association, 60(5), 568-573, doi.org/10.3155 /1047-3289.60.5.568

Skrucany, T., Semanova, S., Figlus, T., Sarkan, B., and Gnap, J. (2017). Energy intensity and GHG production of chosen propulsions used in road transport. Communications-Scientific Letters of the University of Zilina, 19(2), 3-9.

Song, Q., Wang, Z., Wu, Y., Li, J., Yu, D., Duan, H., and Yuan, W. (2018). Could urban electric public bus really reduce the GHG emissions: A case study in Macau? Journal of Cleaner Production, 172,
2133-2142.

Tan, X.; Tu, T.; Gu, B.; Zeng, Y.; Huang, T.; Zhang, Q. (2021). Assessing $\mathrm{CO}_{2}$ Emissions from Passenger Transport with the Mixed-Use Development Model in Shenzhen International Low-Carbon City. Land, 10, 137, doi.10.3390/land10020137

Tokuşlu, A. (2021). Calculation of Aircraft Emissions During Landing and Take-Off (LTO) Cycles at Batumi International Airport, Georgia. International Journal of Environment and Geoinformatics, 8(2), 186-192, doi. 10.30897/ ijegeo.836780

Ülker, D., Ergüven, O., Gazioğlu, C. (2018). Socioeconomic impacts in a Changing Climate: Case Study Syria . International Journal of Environment and Geoinformatics, 5(1), 84-93, doi. 10.30897 /ijegeo.406273

Ülker, D., Bayırhan, İ., Mersin, K., Gazioğlu, C. (2020). A comparative $\mathrm{CO} 2$ emissions analysis and mitigation strategies of short-sea shipping and road transport in the Marmara Region, Carbon Management, 11(6): doi.10.1080/ 17583004. 2020.1852853.

Vásquez, L., Iriarte, A., Almeida, M., and Villalobos, P. (2015). Evaluation of greenhouse gas emissions and proposals for their reduction at a university campus in Chile. Journal of Cleaner Production, 108, 924-930.

Wara, S. T., and Ologun, O. O. (2012). Carbon Footprint Evaluation and Reduction as A Climate Change Mitigation Tool- Case Study of Federal University of Agriculture Abeokuta, Ogun State, Nigeria. In Mitigation and Adoption to Climate Change; Social Economic and Engineering Perspectives (pp. 17-32). Arusha, Tanzania: Institution of Engineers, Tanzania.

Weitzman, M. L. (2012). GHG targets as insurance against catastrophic climate damages. Journal of Public Economic Theory, 14(2), 221-244.

WRI. (2008). World Resources Institute Carbon Dioxide (CO2) Inventory Report For Calendar Years 2006 and 2007. Washington, DC.

$\mathrm{Xu}$, B., and Lin, B. (2015). How industrialization and urbanization process impacts on $\mathrm{CO} 2$ emissions in China: evidence from nonparametric additive regression models. Energy Economics, 48, 188202.

Yan, X., and Crookes, R. J. (2009). Reduction potentials of energy demand and GHG emissions in China's road transport sector. Energy Policy, 37(2), 658668. 